\title{
JOURNAL.RU
}

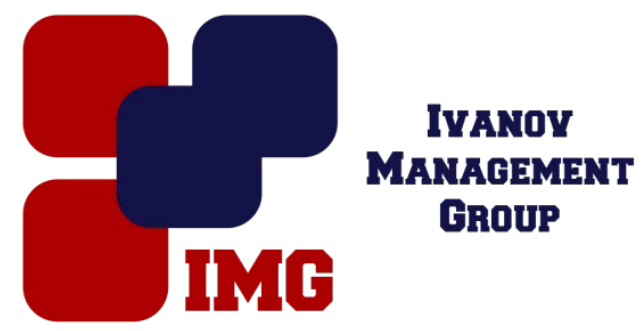

Kovinko I.A. Tyumen State University

Tyumen, Russia

doi: 10.18411/lj-31-03-2017-1-04

idsp 000001:1j-31-03-2017-1-04

\section{The evolution of the ecological concepts in the context of sociological surroundings}

\begin{abstract}
The modern process of ecologization is the step of the relation between society and nature. Today in many European countries ecological knowledge penetrates almost all disciplines and most spheres of human activity -economy, policy, and culture. There were a lot of thought and specific steps to come to make it real in the society. Russian political aims in the ecological government differ from modern Western theories. One of the reasons can be short historical development of this type of science.

Keywords: environmental risk, social theory, ecological movement, Russian ecosociology.

First modern ecological problems were discovered in the 60th of the twentieth century in developed Western countries. They were connected with huge and rapid postwar economic growth in industry, which caused different negative environmental effects. In that period of time arose the question about rethinking the relations between the environment and society. This step can be designated as the first step in the sphere of environmental relations. Environmental paradigms in Western society were changing with the course of socio-economic trends. Firstly, European value system was aimed at increasing profitability, efficiency and consumption rates. But soon things began to change and there were first discussions about the imminent global catastrophe, the prevention of which researchers saw in the reconstruction of the entire structure of society. Also at that time, the active formation of social protest movements began, characterized by consistent of the non-conformism, criticism and opposition to the official ideology.

The next development of the Ecological Movement made possible to formulate a new environmental paradigm, which allowed identifying the key of socio-cultural attitudes of society towards industrial growth, progress, politics, relationships between man and nature. The important things were: the rejection of the anthropocentrism and the
\end{abstract}


recognition of the human as a part of the ecosystem. All environmental problems and solutions from the local grade began to move into the regional and global level. Further formation of the social ecology is divided to the concept of risk. Industrial pollution, which has an accumulative effect, achieved a great expansion that time. This can cause great problems not today, but after some period of time. The research of the environmental risk in social theory has led to the concept by Ulrich Beck (1984). He brought this beyond the functioning of technological systems by defining the modern society as the universal, unpredictable society of the risk. Except U.Beck, this theme was explored by other modern sociology: A. Giddens, P. Drucker, Luhmann, E. Hoffman, B. McKibben. Anthony Gidens summarized the findings of W. Beck and formulated the concept of reflexive modernization as a constant rethinking and reevaluation of all the institutions of modernization. In his opinion, the social practice is constantly changing, and involves a change in all aspects of public life, including the environment. Also one of the important concepts of that time was proposed by Charles Perrou- the concept of normal or system emergency. The author has analyzed a lot of man-made accidents, and then claimed that all modern technological systems can cause an accident. Such incidents are typical for the any type of industry, regardless of the proposed security measures.

Global society started to realize the awareness of the ecological problems both on the social and political levels. Politics began to talk about the environmental crisis. The example of it is the report of the Prime Minister of Norway Gro Harlem Brundtland, "Our Common Future" in 1987, which announced the idea of sustainable development. Under the influence of environmental movements pro-ecological legislation began to be enrooted. First step to make it possible was the opening of the network of «green markets» that were involved in the creation of "pure" products, which produced with no harm to the environment. The functioning of this mechanism can stimulate proecological evolution of society. The concept of ecological modernization is a scientific theory, which is consisting of the ecological capitalism and the idea of sustainable development. The ideological author is Joseph Huber, who claimed about the reduction of the role of social movements in the pro-ecological activities. According to D.Huber, entrepreneurs play a greater role in public life and possibility of further environmental development.

The main principle of the new super- industrial society is the possibility of achieving simultaneously economic growth and environment protection by modern introduced technologies. According to this strategy social relations are replaced by functional projection. Among the main directions of the theory is protective movement, which advocates the preservation of wildlife and the rise of its value in modern society. Conservatism puts forward the idea that society should ensure the optimal functioning of the ecosystem and prevent its crises and catastrophes. The main role of a man on this planet is to maintain the dynamic equilibrium of ecosystems.

In 1987, Environment International Commission first mentioned the term "sustainable development" in the report "Our Common Future". Under this definition, the commission realized creation of such socio-economic system, which is aimed at a high and quality level of life in all areas: wages, health, education and the environment. 
In 1992, in Rio de Janeiro at the International Conference on Environment and Development, this type of development has been recognized as a priority. Subsequently, this document became the basis of the international agreements in the environmental development. Economic projects that count the laws of nature are more effective and durable. From the environmental point of view, the basis for sustainable development is to preserve and maintain the stability of the natural physical systems in balance. According to many researchers, the transition to this strategy is a long-term, because it takes a long time to solve all the problems concerning poverty, overpopulation of urban agglomerations, political conflicts.

Russian ecosociology as a field of science was formed approximately in the 6070-ies of the last century. She appeared at the junction of two discipline: urban sociology and social psychology. A period of environmental enthusiasm was marked in the USSR in the 1987-1988. The government began to account citizens' demands about ecological problems: to stop the diversion of Siberian rivers to the south and to solve the question about the most unsafe industries. But with the beginning of the disintegration of the Soviet Union, environmental priorities have been pushed into the background. Recently, the Russian development of ecological modernization theories associated with the growth of the importance of global environmental and social problems. These are many manifestations of the ecological crisis and structural social changes, the development of environmental social movements and the dissemination of the eco-friendly lifestyle. But, in general, the transition to sustainable development is not widely spread in Russia. Objectively, the environmental movement weakly uses existing political opportunities to correct nowadays mistakes or to prevent future global catastrophes.

A man for a long time did not pay much attention to the analysis and forecasting of different effects from the physical activity to the environment. Consequently, today there is ecological imbalance in many ways and the condition of the biosphere requires urgent attention. Humanity needs a new structure of society, which involves changes in a way of thinking, styles of behavior and action. The ultimate goal of this process is to harmonize the relationships in the socio-ecological system that will allow people to avoid a global ecological catastrophe.

\section{Литература}

1. Naess Arne. "The shallow and the deep, long-range ecology movement: A summary' Inquiry. 2013. 16 (1): 95-100.

2. WCED, Our Common Future. London. Oxford University Press. 2012.

3. Бек У. Общество риска. На пути к другому модерну (пер. с нем.). М.: ПрогрессТрадиция, 2011.

4. Аксенова О.В. Генезис социально-экологической рефлексии на Западе во второй половине ХХ в., 2014. 